\title{
Effect of Calcium, Boron and Micronutrient Formulations on Berry Cracking in Grapes var. Muscat Hamburg
}

\author{
Parthiban $\mathbf{S}^{1 *}$, Indirani $\mathbf{R}^{2}$, Subbiah $\mathbf{A}^{2}$, Saraswathy $\mathbf{S}^{2}$ and Nireshkumar $\mathbf{N}^{2}$ \\ $1 *$ Department of Fruit Science, Horticultural College and Research Institute, Tamil Nadu Agricultural University, Periyakulam - 625604. \\ ${ }^{2}$ Grapes Research Station, Tamil Nadu Agricultural University, Anaimalayanpatty, Theni - 625526
}

\begin{abstract}
Muscat Hamburg (Panneer) is the most popular cultivar in Tamil Nadu for its pleasant musk flavor. It is consumed as table variety and also used for juice and wine-making purposes. The present investigation was conducted during summer and winter pruning from April 2016 to March 2018, in the grapes vineyard located at Shanmuganathy dam road, Rayappanpatty village in Cumbum valley of Theni district, Tamil Nadu. The experiment was laid out by adopting Randomized Block Design with seven treatments and three replications. The exeprimental results revealed that the treatment with foliar application of chelated EDTA calcium @ 0.2\% + boric acid @ 0.1\% recorded the maximum number of bunches (41.00 vine $\left.{ }^{-1}\right)$, fruit yield $\left(14.87 \mathrm{~kg} \mathrm{vine}^{-1}\right)$, individual bunch weight $(636.87 \mathrm{~g})$, bunch volume $(498.42 \mathrm{~mL})$ and TSS ( $19.53^{\circ}$ brix). The minimum berry cracking $(3.46 \%)$, titrable acidity $(0.52 \%)$ and physiological loss in weight (10.18\%) were also recorded in the treatment with chelated EDTA calcium @ 0.2\% + boric acid @ 0.1\% $\left(\mathrm{T}_{5}\right)$ as compared to other treatments. Further, the same treatment combination noted the lowest berry shattering $(2.42 \%)$. Whereas the highest berry diameter was recorded in the treatment with a spray of calcium chloride @ 0.3\% than all other treatments.
\end{abstract}

Keywords: Berry cracking; Boron; Calcium; Muscat Hamburg; Yield; Quality

\section{INTRODUCTION}

The grapes (Vitis vinifera L.) are one of the most commercially important fruit crops globally. The grape belongs to the family Vitaceae. It is believed to have been originated in Armenia near the Caspian Sea and got introduced into India via Iran and Afghanistan during the $11^{\text {th }}$ century. In the whole world, the production of grapes contributes to about 16 per cent of the total fruit production. Commercial grapevine cultivation in India has been taken up in various soil and climatic conditions. Totally 94 per cent of the cultivated area in grapes is contributed by tropical region. In India, remarkable success has been achieved in table grapes production and it is grown with a total area of 0.13 million hectares with an annual production of 2.95 million tonnes during the year 2018-19. In Tamil Nadu, grapes are grown in 2,487 hectares with an annual production of 0.31 lakh metric tonnes (NHB, 2019). Muscat Hamburg (Panneer) is the most popular cultivar in Tamil Nadu for its pleasant musk flavor consumed as table variety and used for juice and winemaking purposes. Berries are small to medium, spherical, pink to blackish purple, opaque and strongly adherent with pedicel. Pulp is light green, soft, sweet, juicy, light pink, mildly scented, good eating quality with characteristic Muscat flavor (Shikhamany, 2001).

Though the productivity of Muscat Hamburg is high compared to other varieties, the quality is poor owing to the problems like berry cracking, berry shattering and uneven color development. Berry cracking is one of the main disorders in grapes that widely limit yield and quality, leading to a reduction in price, marketability and shelf life. There are many factors like rainfall, temperature, wind, cultivar, nutrition, irrigation, sunlight, skin thickness, etc. that influence the berry cracking (Son and Lee, 2008). Berry cracking is a quantitative trait and several genes control it. The best way to reduce fruit cracking is by adopting proper viticulture management practices, which minimizes the stress of water, nutrition and physiological factors. Further, employing a weather-based decision support system to fix the pruning to avoid the berry maturity and harvesting during the rainy season.

Calcium is an essential structural component of the cell wall in plants and its deficiency in fruit is associated with a wide range of physiological disorders including fruit cracking. Calcium also 
plays an important role in strengthening and stabilizing the cell wall and membrane structure. There is a threefold improvement of fruit quality by calcium, which can be understood by the following conditions viz., under calcium-deficient conditions, deterioration of cell membranes in fruits to a larger extent was observed, it alters the original architecture of cell membranes that changes the fluidity and water permeability. Calcium has a significant effect on membrane integrity and the activity of membrane-bound enzymes in that it mediates membrane continuity with regard to cell organic constituents. It also activates membranebound ATPase that mediates $\mathrm{K}$ movement. A loss of membrane-bound $\mathrm{Ca}$, either by replacement with $\mathrm{K}^{+}$or through chelation, increases membrane permeability. Calcium binds anionic groups of the membrane structure to form bridges between structural components, thereby maintaining a selective permeability by pore radius or surface charge relations as well as membrane structural integrity (Poovaiah et al., 1988).

Calcium plays a vital role in maintaining the tissue integrity and metabolic activity in plants (Poovaiah et al., 1988). Earlier studies recommended that calcium play an important role in cracking resistance in litchi fruit because trees that have higher calcium levels exhibit lower cracking rate, while a high cracking incidence occurs with low exchangeable calcium in plants. The movement of calcium within the plant is usually from the soil to the leaves and very slight from the leaves to the fruit (Kadir, 2004). Hence, foliar application of calcium on the fruit is important to make stronger cell wall and to reduce the calcium-related physiological disorders.

Calcium applied to the fruit surface, for example, may penetrate only when moisture on the fruit surface is drawn into the fruit by night-time contraction. In all fruits, there is a decline in calcium influx during growth results not only from an increase in solute influx via the phloem during fruit ripening, but also from a decline in cell division rate, reduced formation of new binding sites for $\mathrm{Ca}$ and an increase in volume/surface area, with a reduction in transpiration per unit weight of fruit (Kirkby and Pilbeam, 1984). Xylem Ca transport is mainly directed to leaf tissues with only 5-10 per cent of absorbed $\mathrm{Ca}$ being transported to fruit tissues (Wójcik et al., 2010).

Although the most active uptake of $\mathrm{Ca}$ by the grapevine is between the period bud burst to vèraison, the grapes have a very narrow window for calcium uptake (bloom to véraison), which is a six to seven-week period. The increase of Ca was found to be the fastest during the first stage of berry growth, while an increase post-vèraison was exclusively due to $\mathrm{Ca}$ accumulation in the seeds. Ca transport to skin cells occurs during ripening and because of this, a dramatic reduction in the concentration of $\mathrm{Ca}$ in cells of the flesh occurs. The Ca content in the seed increases throughout the development of the berries, including ripening (Cabanne and Donèche, 2001; During et al., 1987; Schaller et al., 1992; Storey et al., 2003). On the other hand, the calcium accumulation stops when green berries start to soften, often even before vèraison, which is also related to a decrease in xylem flow (Possner and Kliewer, 1985).

The level of $\mathrm{Ca}$ increase in the berry during the active uptake period depends on the weather conditions before vèraison. Cool dry weather between flowering and vèraison reduces calcium uptake (Saxton, 2002). The average Ca concentration of young apples were found to be much higher than mature apples and the amount of $\mathrm{Ca}$ retained by the young fruits is often too small (Schlegel and Schönherr, 2002). Consequently, the evolution of the Ca content in the various berry compartments can vary from year to year or with grapevine cultivar (Cabanne and Donèche, 2003).

Ripening is caused by an increase in membrane permeability and dissolution of the middle lamella, both processes favored by low levels of $\mathrm{Ca}$. Calcium also maintains mitochondrial integrity, the endoplasmic reticulum and other cytoplasmic membranes integrity. Calcium decreases the hydraulic permeability in apple fruit (Poovaiah et al., 1988). Cell and cell wall structure are affected by $\mathrm{Ca}$, $\mathrm{K}$ and $\mathrm{P}$ nutrition (Yang et al., 1997; Cabanne and Donèche, 2001; Saxton, 2002). With rapid growth (which includes berry expansion after véraison) the structural integrity of plant tissues is strongly coupled with Ca availability. If there is a Ca deficiency, intracellular $\mathrm{Ca}$ takes precedence, so the amounts of Ca in the cell wall decreases and cell wall integrity gets reduced (Saxton, 2002). Since it renders the substrate less accessible to polygalacturonase due to the intermolecular cross-links within the pectic polysaccharide matrix, Ca reduces cell wall breakdown. Profound modifications occur in the cell structure of berry flesh during ripening, stating that it is due to the solubilization of pectins brought about by the migration of $\mathrm{Ca}$ from the flesh. The result is a net degradation of the cell wall that takes place during ripening. Cell cohesion seems to play an important role in the textural quality of fruit. This is obtained by cell-to-cell contact, especially regarding the middle lamella, which is rich in pectinaceous materials and contributes to cell cohesiveness. This area is an essential site for Ca interaction. So, with pectic polysaccharides being particularly abundant in the middle lamellar region, the bridges that form with Ca between these polymers ensure flesh firmness (Poovaiah et al., 1988). Pectic substances,

$107|10-12| 2$ 
cross-linked inter-and intra-molecular by $\mathrm{Ca}$, are thought to be largely responsible for tissue rigidity.

Wojcik et al., (2010) found that Ca applied directly to the fruit can have low penetration, depending on the epidermis characteristics and the cuticle presence and composition, which affects its permeability. All of these parameters vary throughout the growing season. The chelated form of Ca on apple enhanced Ca content of the fruit and fruit firmness (Wójcik et al., 2010).

Boron is a vital micronutrient involved in cell wall development, cell division, phloem development and movement of sugars, metabolism of nitrogen and phosphorus and absorption of salts. Lack of boron symptoms involves wilting, curling, cracking, leaf thickening and also fruit discoloration. The effect of boron deficiency brings about a decrease in the amount of $\mathrm{Ca}$ linked with pectin constituents of the cell wall recommended that boron may be necessary in Ca metabolism in the cell wall (Yamaguchi et al., 1986; Peryea et al., 2003).

Adequate boron nutrition is critical not only for high yields but also for a high quality of crops. The primary effect of boron deficiency appears to be the disruption of the normal functioning of the apical meristems with changes in membrane structure, cell-wall synthesis, metabolisms of auxin, carbohydrate, ascorbate and RNA and lignification, phenol accumulation and sucrose transport being secondary effects (Khanduja et al., 1976) Under boron deficiency, apple fruits may also have low concentrations of soluble solids and acids. It is also involved in carbohydrate and phenolic metabolism and translocation of meristems, cell division, cell wall construction and integrity of the membranes.

The primary cell wall is an important factor determining cell size and shape during plant development in higher plants. Up to 90 per cent of the cellular boron has been localized in the cell-wall fraction where it is associated with pectinacious compounds (Hu and Brown 1994). Hence, the first symptoms of boron deficiency include abnormalities in the cell wall and middle lamella organization. Boron performs a physical role in maintaining cell-wall extensibility and under boron-deficient conditions, the cell wall becomes rigid, inelastic, and brittle. Borate esters with hydroxyl groups of cell-wall carbohydrates and/or glycoproteins has been proposed as a mechanism for cross-linking cell-wall polymers. Boron plays an important role in maintaining plasma membrane integrity, possibly by linking glycoprotein and glycolipid components of the plasma membrane bilayer through its ability to complex $\mathrm{OH}$-containing polysaccharides. Moreover, it enhances the marketable fruit yield of many fruits by decreasing physiological disorders like cracking to a great extent. Boron can be involved in a number of metabolic pathways and can regulate metabolic processes similar to plant hormones. Barr et al. (1993) showed that boron instantaneously stimulated the auxin-sensitive plasmalemma $\mathrm{NADH}$ oxidase. By stimulating NADH oxidase, boron could be involved in keeping ascorbate reduced at the cell-wall/ membrane interface.

In keeping the above said reasons, the present investigation on pre-harvest foliar spray of chelated EDTA micronutrient mixture, calcium and boron formulations on yield and quality of grapes var. Muscat Hamburg.

\section{MATERIAL AND METHODS}

The present experiment was conducted during the summer and winter season pruning season from April 2016 to March 2018 in the grapes vineyard of Th. P. Murugan situated in Shanmuganathy dam road, Rayappanpatty village, Cumbum valley, Theni district, Tamil Nadu. The nutrient management and viticulture practices were followed as per the standard package of practices, irrespective of treatments. The experiment was laid out by adopting the Randomized Block Design with seven treatments replicated thrice. Six vines of uniform growth and fruiting potential were selected at random for observation. The treatments details viz., T1 - Chelated EDTA micronutrient mixture @ 0.2\%, T2 - Chelated EDTA calcium @ 0.2\%, T3 - Boric acid @ 0.1\%, T4 - Calcium chloride @ 0.3\%, T5 - Chelated EDTA calcium @ 0.2\% + boric acid @ 0.1\%, T6 Calcium chloride @ 0.3\% + boric acid @ 0.1\% and T7 - Control. During the berry development and veraison stage, the spraying was carried out by covering whole bunches and leaves. The observations on yield and quality characters viz., stalk length $(\mathrm{cm})$, number of bunches vine ${ }^{-1}$, individual bunch weight $(\mathrm{g})$, bunch volume $(\mathrm{mL})$, length of the bunch $(\mathrm{cm})$, length of the rachis $(\mathrm{cm})$, number of berries bunch-1, berry diameter $(\mathrm{mm})$, individual berry weight $(\mathrm{g})$, number of seeds per berry, fruit yield (kg vine $\left.{ }^{-1}\right)$, juice recovery (\%), TSS (degree brix ), titrable acidity, total anthocyanin content (mg 100 $\mathrm{g}^{-1}$ ), berry cracking (\%), PLW (\%), berry shattering (\%) and bunch weight (kg) was recorded. The berry shattering percentage of grapes was calculated on per cent weight basis by measuring the weight of shattered berries from each bunch and dividing them by the total weight of the same bunch. The per cent loss in weight after the final day of ambient storage ( $7^{\text {th }}$ day after harvest) was calculated by subtracting the final weight from the initial weight of the fruits. The cumulative loss in weight was calculated on a fresh weight basis. The data were subjected to statistical scrutiny by adopting the methods of Panse and Sukhatame (1985). 


\section{RESULTS AND DISCUSSION}

\section{Effect of pre-harvest sprays on yield and bunch characters}

The observations on stalk length $(\mathrm{cm})$, number of bunches vine ${ }^{-1}$, individual bunch weight (g), bunch volume $\left(\mathrm{cm}^{3}\right)$, length of the bunch $(\mathrm{cm})$, length of rachis $(\mathrm{cm})$, number of berries bunch ${ }^{-1}$ and number of seeds per berry was recorded and presented in table 1 . The maximum number of bunches $(41.00$ vine $^{-1}$ ) was registered in the treatment $\mathrm{T}_{6}$ (Calcium chloride @ 0.3\% + boric acid @ 0.1\%). The highest average yield (14.87 kg vine $\left.{ }^{-1}\right)$ was recorded in the pre-harvest spray of chelated EDTA calcium @ 0.2\% + boric acid @ 0.1\%. Application of calcium and boric acid might be helpful in developing cell growth and reducing the dropping of pin heads after fruit set, ultimately leads to enhance the number of bunches $v^{2} e^{-1}$. Whereas the highest yield vine ${ }^{-1}$ recorded in the pre-harvest spray with chelated EDTA calcium @ $0.2 \%$ + boric acid @ 0.1\% might be due to the better absorption of calcium into the cell wall, owing to its chelated form. The cumulative effect of calcium and boron ultimately improved the proper filling, cell wall thickness and solids accumulation in the berry. In apples, fruit size was also found to affect the $\mathrm{Ca}$ concentration, with larger fruit having lower Ca concentrations (Drake et al., 1979). The maximum number of berries bunch ${ }^{-1}(122.43)$ was observed in the treatment of boric acid @ 0.1\%. The maximum number of berries bunch ${ }^{-1}$ was observed in the treatment of boric acid @ $0.1 \%$. The increased number of berry bunch ${ }^{-1}$ after the berry setting stage in grapes might be due to the support of boron in the reduction of fruit abscission by involving ascorbate metabolism (Barr et al., 1993). Whereas, the maximum individual bunch weight (363.87 g) was registered in the treatment $\mathrm{T}_{5}$ (Chelated EDTA calcium @ 0.2\% + boric acid @ 0.1\%). The maximum number of seeds per berry (2.92) was observed in the treatment $\mathrm{T}_{6}$ (Calcium chloride @ 0.3\% + boric acid @ 0.1\%). Ca as foliar applications can increase the yield and berry size of Italia grapes and enhance sugar accumulation (Drake et al., 1979; Sen et al., 2010). The maximum number of seeds berry ${ }^{-1}$ was observed in the treatment $\mathrm{T}_{6}$ (Calcium chloride @ $0.3 \%$ + boric acid @ 0.1\%). These findings were corroborated with the earlier works of Bonomelli and Ruiz (2010) and Ciccarese et al. (2013).

Tables 1. Effect of berry cracking management on yield characters in grapes var. Muscat Hamburg

\begin{tabular}{|c|c|c|c|c|c|c|c|}
\hline Treatments & $\begin{array}{c}\text { No. of } \\
\text { bunches vine } e^{-1}\end{array}$ & $\begin{array}{c}\text { Bunch } \\
\text { weight (g) }\end{array}$ & $\begin{array}{l}\text { No. of } \\
\text { berries } \\
\text { bunch-1 }^{-1}\end{array}$ & $\begin{array}{l}\text { Individual } \\
\text { berry weight } \\
\text { (g) }\end{array}$ & $\begin{array}{l}\text { No. of } \\
\text { seeds } \\
\text { berry }^{-1}\end{array}$ & $\begin{array}{l}\text { Fruit yield } \\
\left(\text { kg vine }^{-1}\right)\end{array}$ & $\begin{array}{c}\text { Calculated } \\
\text { fruit yield } \\
\left(\mathrm{kg} \mathrm{ha}^{-1}\right)\end{array}$ \\
\hline $\mathrm{T}_{1}$ & 35.23 & 326.41 & 102.27 & 2.33 & 1.91 & 11.52 & 15.99 \\
\hline$T_{2}$ & 32.71 & 317.65 & 104.05 & 2.67 & 2.58 & 10.40 & 14.43 \\
\hline $\mathbf{T}_{3}$ & 36.33 & 321.29 & 122.43 & 3.61 & 2.45 & 11.68 & 16.21 \\
\hline$T_{4}$ & 34.66 & 324.26 & 109.89 & 3.88 & 2.80 & 11.25 & 15.62 \\
\hline$T_{5}$ & 40.88 & 363.87 & 115.22 & 3.26 & 2.25 & 14.87 & 20.64 \\
\hline $\mathbf{T}_{6}$ & 41.00 & 348.87 & 103.52 & 3.19 & 2.92 & 14.32 & 19.87 \\
\hline $\mathbf{T}_{7}$ & 30.67 & 286.92 & 87.21 & 2.93 & 2.41 & 8.76 & 12.17 \\
\hline SE (d) & 1.70 & 21.67 & 9.43 & 0.30 & 0.127 & 1.49 & 2.42 \\
\hline$C D(p=0.05)$ & 3.74 & 47.74 & NS & 0.67 & 0.28 & 3.27 & 5.33 \\
\hline
\end{tabular}

\section{Effect of pre-harvest sprays on berry and bunch quality characters}

The observations on length of the rachis $(\mathrm{cm})$, stalk length $(\mathrm{cm})$, bunch volume $(\mathrm{mL})$, berry diameter ( $\mathrm{mm}$ ), individual berry weight (g), juice recovery (\%), TSS ( ${ }^{\circ}$ brix), titrable acidity and total anthocyanin content $\left(\mathrm{mg} \mathrm{100g}^{-1}\right)$ were recorded and presented in table 2. The mean values for stalk length were ranged from 0.88 to $1.21 \mathrm{~cm}$ and the highest stalk length (1.14) and berry diameter (7.53) was observed in calcium chloride spray @ 0.3\%. This might be due to the positive influence of calcium on cell division, cell elongation, calcium deposition, berry turgor, osmotic pressure and strengthening of cell wall. It is well documented for different crops like pear, cherries and strawberry that boron plays an important role both in the structural and functional integrity of membranes and cell-wall formation. An increase in total soluble solids could be attributed to the transportation of a higher amount of assimilates into fruit tissues. The observations on length of rachis and TSS were found to be non-significant among treatments. The boric acid might have facilitated sugar transport through artificial lipid bilayer membranes. This was supported from the works of Singh et al. (2006) and Wójcik and Wójcik (2006) by boron and/or calcium spray obtained big sized apples, high sugar content, and anthocyanin. The treatment $\mathrm{T}_{5}$ (Chelated EDTA calcium @ 0.2\% + boric acid @ 0.1\%) resulted maximum bunch volume (498.42 ml), length of bunch $(19.75 \mathrm{~cm})$ and length of rachis $(19.37 \mathrm{~cm})$. Similar findings were reported by Ciccarese et al. (2013) in Italia grapes and Karimi (2017) in Sultana grapes. The highest values for TSS (19.53 ${ }^{\circ}$ Brix) and total anthocyanin content (32.22 $\mathrm{mg} 100 \mathrm{~g}^{-1}$ ) were documented in the treatment with

$107 \mid 10-12$ | 4 
foliar application of chelated EDTA calcium @ 0.2\% + boric acid @ 0.1\%. The highest juice recovery was $(61.66 \%)$ registered in pre-harvest spray of calcium chloride @ 0.3\% + boric acid @ 0.1\%. $\mathrm{T}_{5}$ (Chelated EDTA calcium @ 0.2\% + boric acid @ 0.1\%) registered the maximum value for TSS, anthocyanin content, bunch volume, length of bunch and length of rachis. Calcium supplements increased the TSS, which may improve anthocyanin accumulation by activating transcription factors. Pre-harvest boron application had a substantial effect on several physiological parameters and on the storability by improving the ability of fruit tissue to resist impaired storage conditions. Earlier works of Thurzo et al. (2010) in sweet cherries substantiated the present view. In Muscat Hamburg grapes, foliar application of boron at 0.3 per cent with the frequency of two sprays resulted in increasing the total soluble solid content, and the lowest acidity was recorded (Janaki et al., 2002). Makhija et al. (1988) Makhija and Chandra (1992) in Perlette grapes and Mostafa et al. (2006) reported that foliar nutrition of boric acid progressively increased the TSS and reduced the titrable acidity in grapes are in corroboration with present findings.

Table 2. Effect of berry cracking management on quality characters in grapes var. Muscat Hamburg

\begin{tabular}{|c|c|c|c|c|c|c|c|c|c|}
\hline Treatments & $\begin{array}{c}\text { Bunch } \\
\text { volume } \\
(\mathrm{mL})\end{array}$ & $\begin{array}{l}\text { Length } \\
\text { of bunch } \\
\text { (cm) }\end{array}$ & $\begin{array}{l}\text { Length } \\
\text { of rachis } \\
(\mathbf{c m})\end{array}$ & $\begin{array}{l}\text { Berry stalk } \\
\text { length } \\
\text { (cm) }\end{array}$ & $\begin{array}{l}\text { Berry } \\
\text { diameter } \\
(\mathbf{m m})\end{array}$ & $\begin{array}{c}\text { Juice } \\
\text { recovery (\%) }\end{array}$ & TSS ('brix) & $\begin{array}{l}\text { Titrable } \\
\text { acidity } \\
\text { (\%) }\end{array}$ & $\begin{array}{l}\text { Total anthocyanin } \\
\text { content (mg } \\
\left.100 \mathrm{~g}^{-1}\right)\end{array}$ \\
\hline$T_{1}$ & 368.92 & 17.81 & 16.63 & 0.83 & 5.66 & 51.51 & 17.67 & 0.74 & 19.20 \\
\hline $\mathbf{T}_{2}$ & 385.09 & 16.83 & 15.98 & 0.78 & 6.25 & 57.93 & 18.02 & 0.71 & 21.74 \\
\hline$T_{3}$ & 359.17 & 16.49 & 15.62 & 1.03 & 6.81 & 55.45 & 17.98 & 0.70 & 20.56 \\
\hline$T_{4}$ & 368.58 & 18.66 & 17.28 & 1.14 & 7.53 & 58.48 & 18.85 & 0.52 & 26.58 \\
\hline $\mathbf{T}_{5}$ & 498.42 & 19.75 & 19.37 & 0.92 & 6.88 & 59.47 & 19.53 & 0.52 & 32.22 \\
\hline $\mathbf{T}_{6}$ & 441.37 & 17.81 & 17.11 & 0.99 & 6.25 & 61.66 & 17.52 & 0.72 & 21.17 \\
\hline $\mathrm{T}_{7}$ & 328.70 & 16.21 & 16.59 & 0.95 & 6.72 & 55.20 & 18.05 & 0.75 & 21.04 \\
\hline SE (d) & 20.83 & 0.27 & 1.08 & 0.05 & 0.25 & 1.45 & 0.96 & 0.06 & 1.19 \\
\hline$C D(p=0.05)$ & 45.89 & 0.59 & NS & 0.11 & 0.55 & 3.19 & NS & 0.12 & 2.63 \\
\hline
\end{tabular}

\section{Effect of pre-harvest sprays on berry quality characters}

The observations physiological loss in weight (per cent) was found to be significant among treatments (Table 3 ). Berry cracking caused by rainfall before harvest is a big and severe problem for grape growers in many parts of the world. Various factors are responsible for cracking, including fluctuation in soil moisture regimes, climate, rainfall, nutrition, powdery mildew and cultivars. Physiological mechanisms that have been studied to explain cracking include water uptake by the berries, osmotic potential, anatomical aspects of cells (number and size), physical properties of the cuticle and dynamics of berry growth (Lang and During, 1990).

Research on grape skin indicates that cracking is due to the inferior surface of the skin, the berry shape i.e. long oval with a pericarp that can be easily deformed and a thinner cell wall of the subepidermal cell layer. Personal observation indicates this cracking occurs most often on the fruit's blossom end and sides; splitting near the base of the stem is less common. An increase in subepidermal cell layers also increases the resistance to splitting (Meynhardt, 1964).

Generally, berry skin has been considered as a "thin shell" that tolerates pressure from the internal flesh. This berry skin failure happens due to cell wall fraction rather than cell separation, which signifies that either skin cells have mostly strong intercellular bonding or failure occurs due to high skin cell turgor or both. Splitting resistance depends in part on the extent to which a grape can accommodate a period of rapid volume growth without damage and this depends on the mechanical properties of its skin.

There is a significant increase in water flowing into the berry when water on the surface of the stalk and berry is absorbed by the berry cells. The fruit cracking mechanism was based on the water penetrating the fruit surface, which results in an increase in the volume of the fruit, which causes cracking. Some other research on cracking indicated that the water uptake by the fruit from the root system can build up internal turgor pressure of fruit which also plays an important role in the cracking mechanism (Considine and Kriedeman, 1972). Root uptake is not the primary means of water intrusion into the berry but instead, diffusion across the berry skin is the major pathway. Further water uptake is through an unidentified pathway associated with the berry stem receptacle and transpiration is through the berry skin. The properties and function of the fruit cuticle, water-conducting tissues in the tree, and the fruit pedicel, play a key role in the sweet cherry cracking mechanism (Sekse, 1998). 
Foliar application of chelated EDTA calcium @ $0.2 \%$ + boric acid @ $0.1 \%\left(\mathrm{~T}_{5}\right)$ resulted in the lower values for berry cracking (3.46\%), number of cracked berries ( $8.13 \mathrm{~kg}^{-1}$ fruit) and berry shattering $(2.42 \%)$ and data presented in figure $1,2 \& 3$. Berry skin thickness is a desirable quality characteristic because an imbalance in cell turgidity, extensibility, and elasticity could lead to fruit cracking (Considine and Kriedemann,1972). Application of calcium as foliar spray could not significantly reduce the berry cracking in grapes (Huang et al., 2005). Spraying of calcium compounds and $\mathrm{GA}_{3}$ on young fruits is reported to improve grapes' quality and tends to minimize fruit cracking (Ramteke et al., 2017). But the foliar application of calcium and boron gave better berry cracking reduction than a separate application.

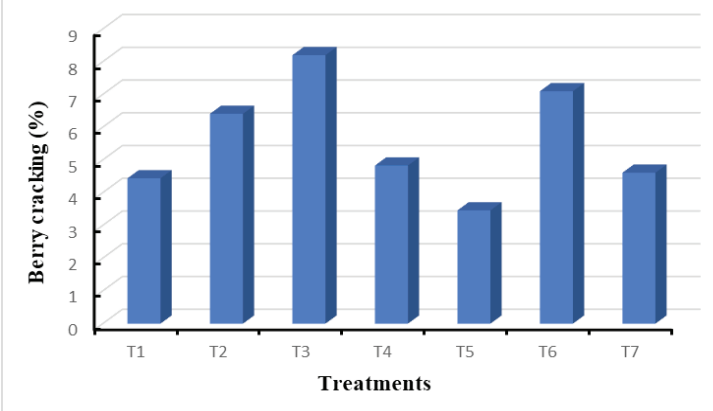

Figure 1. Effect of berry cracking management on berry cracking

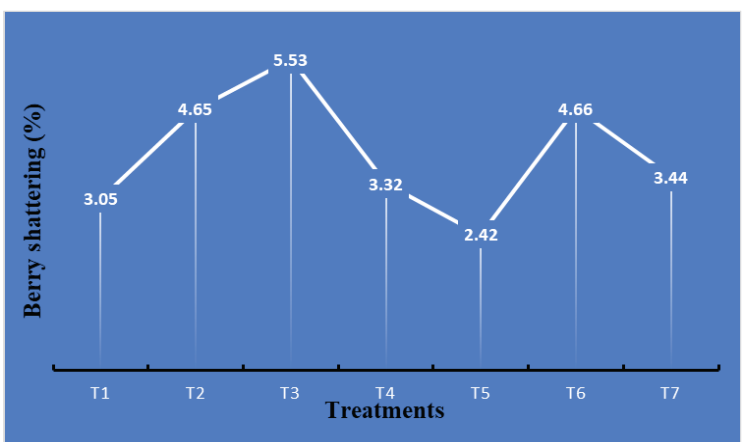

igure 2. Effect of berry cracking management on berry cracking

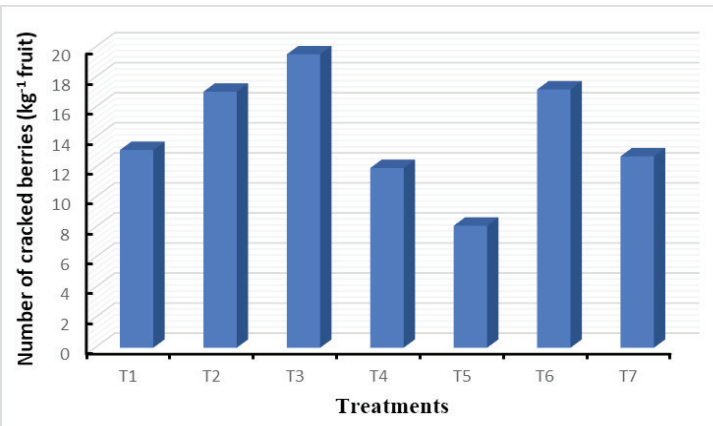

Figure 3. Effect of berry cracking management on number of cracked berries ( $\mathrm{kg}^{-1}$ fruit)
Chelated EDTA calcium @ 0.2\% + Boric acid @ $0.1 \%$ recorded the minimum physiological loss in weight $(10.18 \%)$ and data presented in figure 4 . Boron foliar spray can promote calcium uptake in berries or its metabolism in the cell wall. Calcium boron complex spray results in increased cell wall thickness compared to all other treatments. Boron is involved in pectin synthesis in cells, cell membranes elasticity and prevents the breakdown of vegetative tissues. The addition of exogenous boric acid to lowboron cells, caused an instantaneous stimulation of the plasma membrane NADH oxidase, which was the fastest boron response reported. Thus, boron treatment of low boron plants stimulates ATPase activity, NADH oxidase activity and ion transport (Wójcik et al., 2010) investigated that better absorption of foliar-applied boron and retranslocation through phloem mobility in apple supported the present studies in grapes.

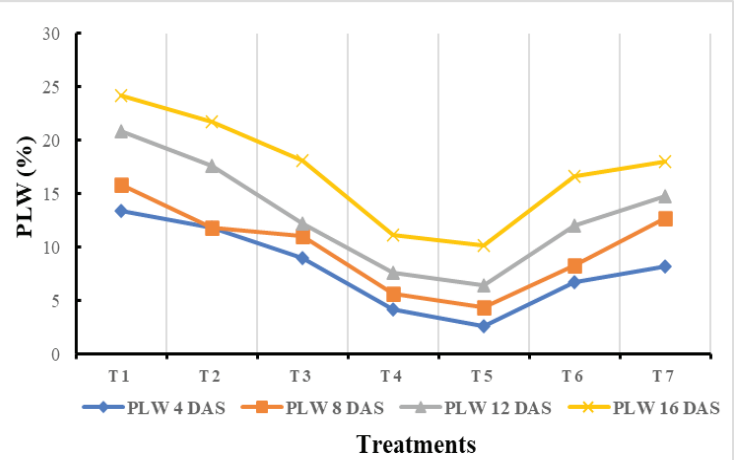

Figure 4. Effect of berry cracking management on PLW (\%)

\section{CONCLUSION}

The present investigation resulted in the reduction of berry cracking disorder in grapes var. Muscat Hamburg to large extent. Further, the results obtained from the experiment revealed that the treatment with foliar application of chelated EDTA calcium @ 0.2\% + boric acid @ 0.1\% recorded the maximum number of bunches (44.40 vine ${ }^{-1}$ ), fruit yield $\left(17.95 \mathrm{~kg}\right.$ vine $\left.{ }^{-1}\right)$, individual bunch weight (431.53), bunch volume (498.42 $\mathrm{mL}$ ) and TSS (19.53ํix). The minimum berry cracking (3.46\%), number of cracked berries (8.13 $\mathrm{kg}^{-1}$ fruit) and berry shattering $(2.42 \%)$ were recorded by chelated EDTA calcium @ 0.2\% + boric acid @ 0.1\% $\left(\mathrm{T}_{5}\right)$ as compared to other treatments. Calcium chloride @ $0.3 \%\left(T_{4}\right)$ recorded highest berry diameter $(7.53 \mathrm{~mm})$ than other treatments

\section{Ethics statement}

This article does not contain any studies with human participants or animals performed by any of the authors. 


\section{Consent for publication}

All the authors agreed to publish the content.

\section{Competing Interests}

The authors declare no conflict of interest in publication of this content.

\section{REFERENCES}

Barr, R., M. Bottger and F. L. Crane. 1993. The effect of boron on plasma membrane electron transport and associated proton secretion by cultured carrot cells. Biochem. Mol. Biol. Inter., 31: 31-39.

Bonomelli, C. and R. Ruiz. 2010. Effects of foliar and soil calcium application on yield and quality of table grape cv. "Thompson Seedless". J. Plant Nutr., 33: 299 - 314.

Cabanne, C. and B. Donèche. 2001. Changes in polygalacturonase activity and calcium content during ripening of grape berries. Am. J. Enol. Vitic., 52: 331 - 335.

Cabanne, C. and B. Donèche. 2003. Calcium accumulation and redistribution during the development of grape berry. Vitis, 42: 19 - 21.

Ciccarese, A., A. M. Stellacci, G. Gentilesco and P. Rubino. 2013. Effectiveness of pre-and postveraison calcium applications to control decay and maintain table grape fruit quality during storage. Postharvest Biol. and Tech., 75: 135-141.

Considine, J. A. and P. E. Kriedemann. 1972. Fruit splitting in grapes: determination of the critical turgor pressure. Australian J. Agric. Res., 23: 17-24.

Drake, M., W.J. Bramlage and J. H. Baker. 1979. Effects of foliar calcium on McIntosh apple storage disorders. Commun. Soil Sci. Plant Anal., 10: 303 - 309

$\mathrm{Hu}, \mathrm{H}$. and P. H. Brown. 1994. Localization of boron in cell walls of squash and tobacco and its association with pectin: evidence for a structural role of boron in the cell wall. Plant Physiol., 105: 681-689.

Huang, X., Wang, H., Yuana, W., Lu, J., Yin, J.H., Lou, S. and $\mathrm{H}$. Huang. 2005. A study of rapid senescence of detached litchi: Roles of water loss and calcium. Postharvest Biol. Tech., 36: 177 - 189.

Janaki, D., V. Velu and P. Savithri. 2002. Influence of boron spray on grapes yield (Vitis vinifera) cv. Muscat in Thondamuthur block of Coimbatore district. Madras Agric. J., 85:21-25.

Kadir, S. A. 2004. Fruit quality at harvest of 'Jonathan' apple treated with foliarly-applied calcium chloride. J. Plant Nutr., 27: 1991 - 2006.

Karimi, Rouhollah. 2017. Potassium-induced freezing tolerance is associated with endogenous abscisic acid, polyamines and soluble sugars changes in grapevine. Scientia Horticulturae 215:184-194.

Khanduja, S., V. Balasubrahmanyam and O. Agnihotri. 1976. Effect of boron on fruit quality, nucleic acid and protein content of leaves in grapevine. Indian J. Horticulture., 33 (3 \& 4): 216-219.
Kirkby, E.A. and D. J. Pilbeam. 1984. Calcium as a plant nutrient. Plant Cell Environ., 7: 397 - 405.

Lang, A. and H. During. 1990. Grape berry splitting and some mechanical properties of the skin. Vitis., 29: $61-70$.

Makhija, M., C. Atul, and R. Yamadagni. 1988. Note on physico-chemical characters of grape berries in cultivar perlette as influenced by foliar application of chemicals. Curr. Agric., 12: 99-100.

Makhija, M., and A. Chandra. 1992. A note on berry quality improvement in Perlette grape by chemicals. Haryana J. of Hort. Sci., 21: 66-66.

Meynhardt, J.T. 1964. A histological study of berrysplitting in some grape cultivars. South African J. Agric. Sci., 7: 707-716.

Mostafa, E., M. El-Shamma and L. Hagagg. 2006. Correction of boron deficiency in grapevines of Bez-El-Anaza cultivar. Eurasian Jounal of Agriculture and Env. Sci., 1: 301-305.

Panse, V.G. and Sukhatme, P.V., 1954. Statistical methods for agricultural workers. Statistical methods for agricultural workers.

Peryea, F. J., D. Neilsen and G. Neilsen. 2003. Boron maintenance sprays for apple: early season applications and tank mixing with calcium chloride. Hort. Sci., 38: 542-546.

Poovaiah, B.W., G. M. Glenn and A.S.N. Reddy 1988. Calcium and fruit softening: physiology and biochemistry. Hort. Reviews., 10: 107 - 152.

Possner, D.R.E and Kliewer, W.M., 1985. The localisation of acids, sugars, potassium and calcium in developing grape berries. Vitis., 24: 229 - 240.

Ramteke, S. D., V. Urkude, S. D. Parhe and S. R. Bhagwat. 2017. Berry cracking: Its causes and remedies in grapes - A Review. Trends in Biosci., 10(2): 549 - 556.

Saxton, V., 2002. Calcium in viticulture - unravelling the mystique of French terroir. Wine Ind. J., 17: 28- 33.

Schaller, K., O. Löhnertz and V. Chikkasubbanna. 1992. Calcium absorption by the grape berries of different cultivars during growth and development. Vit. Enol. Sci., 47: 62 - 65.

Schlegel, T.K. and J. Schönherr. 2002. Penetration of calcium chloride into apple fruits as affected by stage of fruit development. Proc. IS Foliar Nutrition, Tagliavini et al. (Eds.), Acta Hort., 594: 527 - 533.

Sen, K., I. Karacali, M. E. Irget, O. L. Elmaci and M. Tepecik. 2010. A new strategy to enrich calcium nutrition of fruit: synergistic effects of postharvest foliar calcium and boron sprays. J. Plant Nutr., 33: 175 - 184.

Sekse, L. 1998. Fruit cracking mechanism in sweet cherries (Prunus avium L.) - A Review. Acta Hort., 468: 637-648.

Shikhamany, S.D. 2001. Grape production in India. In: Grape production in the Asia Pacific Region (Minas, K. P. and F. J. Dent (Eds.). FAO regional Office for Asia, New Delhi.

Singh, R., R. R. Sharma and S. K. Tyagi. 2006. Preharvest foliar application of calcium and boron 
influences physiological disorders, fruit yield and quality of strawberry (Fragaria ananassa Duch.). Sci. Hortic., 112: 215 - 220.

Son, I. C. and C. H. Lee. 2008. The effects of bags with different light transmittance on the berry cracking of grape 'Kyoho'. Hort. Env. and Biotech., 49(2): 98-103.

Storey, R., R.G.W. Jones, D. P. Schachtman and M.T. Treeby. 2003. Calcium-accumulating cells in the meristematic region of grapevines root apices. Functional PI. Biol., 30: 719 - 727.

Thurzo, S., Z. Szabo, J. Nyeki, A. P. Silva, P. T. Nagy and B. Goncalves. 2010. Effect of boron and calcium sprays on photosynthetic pigments, total phenols and flavonoid content of sweet cherry (Prunus avium L.). Acta Hortic., 868: 457 - 461.
Wójcik, P., H. Gubbuk, H. Akgül, E. Gunes, K. Ucgun, H. Koçal and C. Küçükyumuk. 2010. Effect of autumn calcium spray at a high rate on "Granny Smith" apple quality and storability. J. Plant Nutr., 33: 46 - 56.

Wójcik, P. and M. Wojcik. 2006. Effect of boron fertilization on sweet cherry tree yield and fruit quality. J. Plant Nutri., 29: 1755 - 1766.

Yamaguchi, T., T. Hara and Y. Sonoda.1986. Distribution of calcium and boron in the pectin fraction of tomato leaf cell wall. Plant Cell Physiol., 27: 729-732.

Yang, Y.S., Wu, Y.R., Kuo, Y.K., 1997. Effects of cytokinins and calcium application on the fruit firmness of Honey red grapes. In: Special Publication, Tai'chung District Agricultural Improvement Station., 38, 151-168. 